\title{
Evaluation of Operating Room Environment Contamination and Efficacy of $2 \%$ Chlorhexidine for Surgical Hand Scrubbing before and after Gowning and Gloving
}

\author{
Jessica Lais Gobbo ${ }^{1}$, Marita Vedovelli Cardozo ${ }^{2}$, Luciana de Cenço Corrêa de Lacerda', \\ Débora Emy Karcher', Luís Gustavo Gosuen Gonçalves Dias', Andrigo Barboza de Nardi', \\ Bruno Watanabe Minto' \& Paola Castro Moraes'
}

\begin{abstract}
Background: Human skin is colonized by various species of microorganisms, which makes them difficult to eliminate even with the use of antimicrobial drugs. Real efficacy of the antimicrobial product combined with incorrect administration of antibiotics, in addition to potential environmental contamination, are critical points for the establishment of postoperative infection or absence of it. The main objective of the present study was to evaluate the efficacy of surgical antisepsis using a $2 \%$ chlorhexidine brush during a surgery, detect operating room environmental contamination, and verify the existence of bacterial resistance to the antibiotics most commonly used in Veterinary Medicine.

Materials, Methods \& Results: In ten cases of the surgical routine, samples were collected concurrently at specific time points throughout $2 \mathrm{~h}$ of surgical procedure. To evaluate the efficacy of $2 \%$ chlorhexidine brush on hand scrubbing of a mock surgeon, swabs were used to sample the surface of the hands before and after gowning and gloving. Samples or their dilutions were inoculated onto blood agar and MacConkey agar plates. Contamination of the operating room was evaluated using BHI agar plates distributed through the room. After the incubation period, counts and biochemical tests were performed, and an antimicrobial disc susceptibility test was performed using antibiotics most commonly used in Veterinary Medicine.

Discussion: Even though the surgical unit of the Veterinary Hospital "Governador Laudo Natel" is constantly sanitized, it is not free from microbial contamination. In the present study, there was no bacterial growth on MacConkey agar, which suggests absence of fecal contamination. Blood agar is a culture medium that provides optimal growth conditions to most pathogenic bacteria, which explains the higher microbial growth observed in this medium. Gram-positive cocci grew on blood agar forming grape bunch- and chain-like patterns, which indicates the possible presence of Staphylococcus sp. and Enterococcus sp. The results obtained to evaluate environmental contamination by means of BHI agar revealed growth of diverse microorganisms, with presence of Gram-positive cocci and Gram-negative rods. The biochemical tests indicated presence of microorganisms from various genera. About the evaluation of bacterial resistance to the antibiotics it was possible to observe high bacterial resistance to metronidazole, followed by ampicillin. Metronidazole has bactericidal activity against most of the anaerobic and facultative anaerobic bacteria, since the bacteria found were aerobic. As for ampicillin, it is considered a broad spectrum antibiotic, which indicates that the bacteria found can be resistant to this antibiotic. Clindamycin also resulted in bacterial high resistance, which shows that this drug was not effective against the Grampositive bacteria found in the samples studied. Enrofloxacin yielded high bacterial resistance indicating that wide use of this drug due to its intrinsic efficacy and safety might have contributed to the appearance of resistance. Results showed bacterial resistance to cephalexin, possibly indicating a lower efficacy in treatment against bacterial diseases, since a lot of the samples were Gram-positive. Bacterial resistance to ceftiofur was lower when compared to cephalexin; this can be related to the shorter time this drug has been in the market. The results revealed bacterial growth in the surgical environment, and verified the efficacy of $2 \%$ chlorhexidine for hand scrubbing. Spontaneous mutation and gene recombination contributes to the emergence of resistance is the indiscriminate use of antibiotics for the treatment of animals, which can contribute to bacterial resistance.
\end{abstract}

Keywords: $2 \%$ chlorhexidine, antisepsis, bacterial resistance, environmental contamination, antimicrobials, disinfection. 


\section{INTRODUCTION}

Human skin is colonized by various species of microorganisms that are attached more superficially (transient flora) or more deeply (resident flora), which makes them difficult to eliminate even with the use of antimicrobial drugs [1].

The development of microbial strains resistant to antimicrobial drugs is a result of indiscriminate and excessive use of broad spectrum drugs, as well as automatic repetition of prescriptions, absence of antisepsis, and use of empirical therapy [2].

Lack of hygiene measures combined with the indiscriminate use of antimicrobials is a threat to public health. Chlorhexidine-based antimicrobial soaps are among the products used by veterinarians for hand antisepsis in small animal medicine and surgery [3]. Chlorhexidine has germicidal properties as well as immediate and residual action, with best results for gram-positive bacteria [4].

Real efficacy of the antimicrobial product combined with incorrect administration of antibiotics, in addition to potential environmental contamination, are critical points for the establishment of postoperative infection or absence of it.

Therefore, the aim of the present study was to evaluate the efficacy of $2 \%$ chlorhexidine on antisepsis of the veterinary surgeon's hands by making assessments during the preoperative and intraoperative moments of small animal surgery, and to detect possible bacterial contamination of the surgical environment and resistance to the most common drugs used for prophylaxis and treatment.

\section{MATERIALS AND METHODS}

\section{Sample collection}

This study was conducted at the Veterinary Hospital "Governador Laudo Natel" of Faculdade de Ciências Agrárias e Veterinárias (FCAV) at UNESP, Jaboticabal, SP, Brazil, with the permission and assistance of the Small Animal Clinical Surgery Section. Ten cases from the surgical routine were studied. In each case, samples were collected concurrently at specific time points throughout $2 \mathrm{~h}$ of surgical procedure. Samples were analyzed at the Veterinary Microbiology Laboratory of the Veterinary Pathology Department at FCAV - UNESP, Jaboticabal, SP, Brazil.
To evaluate the efficacy of $2 \%$ chlorhexidine sponges (Escova de Assepsia Riohex Scrub $\left.2 \%{ }^{\circledR}\right)^{1}$ for antisepsis of hands, samples of the surface of a mock surgeon were collected using swabs. The mock surgeon remained sitting by the side of the surgical team of the day and did not participate of the surgical procedure. Swabs were rubbed in circular motion from the wrists to the fingertips (back and palm of the hand); this procedure was repeated three times toward each finger, and the swabs were then transferred to a sterile tube containing peptone water. Samples were collected from the right hand (T0, T1, and T2) and from the left hand (T3) at four time points, as follows: T0 (right hand before antisepsis); T1 (right hand immediately after antisepsis and drying of the hand); T2 (right hand $60 \mathrm{~min}$ after gloving); T3 (left hand 120 min after gloving).

\section{Microbial count}

Bacterial count was performed using the spread plate technique. Serial decimal dilutions were performed (1:10), in which $1 \mathrm{~mL}$ of the sample containing the swab and peptone water was transferred to another tube and so forth, successively. This dilution was necessary to achieve plates with non-overlapping, countable colony-forming units (CFU), as established by APHA [5], which recommends up to $2 \mathrm{CFU} / \mathrm{cm}^{2}$. After the dilution step, $0.1 \mathrm{~mL}$ from each previously diluted tube was inoculated onto blood agar (Ágar Sangue de Carneiro $\left.{ }^{\circledR}\right)^{2}$ to evaluate the presence of the most common microorganisms, such as Staphylococcus and Streptococcus; additionally, $0.1 \mathrm{~mL}$ from each tube was inoculated onto Mac Conkey agar (Mac Conkey $\left.\operatorname{Agar}^{\circledR}\right)^{3}$ to determine the presence of enterobacteria such as Escherichia, Salmonella, Klebsiella, and Enterobacter, among others. After inoculation, samples were spread and homogenized on the dishes containing the culture media using a drigalski spatula.

Indicators of environmental contamination were obtained by four petri dishes containing BHI agar (Brain Heart Infusion $\left.{ }^{\circledR}\right)^{4}$ [Figure 1A], which were distributed around the operating room at the time of the surgical procedures. The plates were distributed as follows: two plates remained close to the main door and two plates remained on countertops, close to and at the same height as the operating table. One plate was taken from each site after $15 \mathrm{~min}$, and the others at the end of the $2 \mathrm{~h}$ period. The simple sedimentation technique endorsed by APHA [5], which recommends up to $30 \mathrm{CFU} / \mathrm{cm}^{2}$, was used to evaluate environmental contamination. 
All of the plates, including those used for environmental contamination evaluation and those used to assess bacterial contamination on the hands of the mock surgeons, were incubated at $37^{\circ} \mathrm{C}$ for 24 $\mathrm{h}$ in microbiological incubators. After the incubation period, microbial counts were performed.

\section{Morphological and biochemical tests}

Morphological and biochemical tests were performed for the identification of bacterial colonies. Bacterial morphology was assessed after Gram staining, which was performed on smears of each sample. To prepare the bacterial smears, aliquots of the cultures were transferred to glass slides and immediately fixed by flaming. The smears were stained with a crystal violet solution for one min. After staining, the slide was covered with lugol's solution for one min. The slide was washed with distilled water. Ethanol-acetone was then dropped on the stained smears, and allowed to act for $15 \mathrm{~s}$. The slide was quickly washed with running water, covered with fuchsine, and allowed to stand for $30 \mathrm{~s}$. The slide was then washed with distilled water and air-dried. The morphology of bacteria stained by the Gram's method was observed under the microscope after adding a drop of oil to the slide. Bacteria were classified into two groups, namely gram-positive and gram-negative.

Biochemical tests (catalase, TSI, urease, motility, citrate, lysine decarboxylase, and lactose) were performed to identify bacterial genera present in the samples.

\section{Antimicrobial susceptibility test}

To perform this test, the isolates were subcultured in a tube containing $3 \mathrm{~mL}$ of $\mathrm{BHI}$ broth and incubated at $37^{\circ} \mathrm{C}$ until turbidity reached McFarland standard no. 0.5. After incubation, the culture was seeded in a dish containing Müeller Hinton agar (Ágar Muller Hinton $\left.{ }^{\circledR}\right)^{3}$ with a sterile swab. After the surface of the culture medium dried, which took approximately 3 min, wafers containing the antibiotics were inserted.

The antimicrobial agents tested were selected according to their use and importance in Veterinary Medicine, and comprised ampicillin $(10 \mu \mathrm{g})$ [AMP $\left.10^{\circledR}\right]^{5}$, chloramphenicol $(30 \mu \mathrm{g})\left[\mathrm{CLO} 30^{\circledR}\right]^{5}$, tetracycline $(30 \mu \mathrm{g})$ [TET $\left.30^{\circledR}\right]^{5}$, ceftiofur $(30 \mu \mathrm{g})$ [CTF - $\left.30 \mathrm{MCG}^{\circledR}\right]^{6}$, metronidazole $(50 \mu \mathrm{g})\left[\mathrm{mtz}-50 \mu \mathrm{g}^{\circledR}\right]^{6}$, cephalexin $(30 \mu \mathrm{g})$ [Cefalexina $\left.30 \mu \mathrm{g}^{\circledR}\right]^{7}$, clindamycin $(2 \mu \mathrm{g})$ [Clindamicina $\left.2 \mu \mathrm{g}^{\circledR}\right]^{7}$, and enrofloxacin $(5 \mu \mathrm{g})$ $\left[\mathrm{ENO}-5 \mathrm{MCG}^{\circledR}\right]^{6}$. The diameters of the zones of inhibition were compared with the CLSI guide [6].

\section{RESULTS}

\section{Microbial count}

The tests performed to detect the presence of possible microbial contaminants in the surgical environment revealed bacterial proliferation on $\mathrm{BHI}$ agar (Table 1).

The results on the efficacy of $2 \%$ chlorhexidine brush for antisepsis of the hands of the mock surgeon showed no microbial proliferation on MacConkey agar $\left(<1 \mathrm{CFU} / \mathrm{cm}^{2}\right)$, while some bacterial growth was observed on blood agar (Table 2).

Table 1. Bacterial growth on BHI agar on the surgical environment expressed in $\mathrm{CFU} / \mathrm{cm}^{2}$.

\begin{tabular}{cccc}
\hline \multicolumn{3}{c}{ Main door } & \multicolumn{3}{c}{ Countertop } \\
\hline $15 \mathrm{~min}$ & $2 \mathrm{~h}$ & $15 \mathrm{~min}$ & $2 \mathrm{~h}$ \\
\hline $1.1 \times 10^{2}$ & $7.6 \times 10^{2}$ & $2.0 \times 10^{1}$ & $3.3 \times 10^{2}$ \\
$9.0 \times 10^{1}$ & $3.3 \times 10^{2}$ & $5.0 \times 10^{1}$ & $2.3 \times 10^{2}$ \\
$<1.0$ & $2.1 \times 10^{2}$ & $2.0 \times 10^{1}$ & $1.7 \times 10^{2}$ \\
$<1.0$ & $2.6 \times 10^{2}$ & $1.0 \times 10^{2}$ & $1.0 \times 10^{2}$ \\
$<1.0$ & $<1,0$ & $2.0 \times 10^{1}$ & $11.0 \times 10^{2}$ \\
$5.0 \times 10^{1}$ & $3.0 \times 10^{2}$ & $6.0 \times 10^{1}$ & $2.0 \times 10^{2}$ \\
$<1.0$ & $<1,0$ & $7.0 \times 10^{1}$ & $2.4 \times 10^{2}$ \\
$3.2 \times 10^{2}$ & $2.0 \times 10^{3}$ & $5.2 \times 10^{2}$ & $2.7 \times 10^{3}$ \\
$<1.0$ & $<1.0$ & $1.4 \times 10^{2}$ & $8.6 \times 10^{2}$ \\
\hline
\end{tabular}


Table 2. Bacterial growth in blood agar before and after antisepsis using $2 \%$ chlorhexidine brush and gowning and gloving, expressed in $\mathrm{CFU} / \mathrm{cm}^{2}$.

\begin{tabular}{ccccc}
\hline \multicolumn{5}{c}{ Blood agar } \\
\hline Sample & M0 & M1 & M2 & M3 \\
\hline 1 & $1.0 \times 10^{2}$ & $<1.0$ & $<1.0$ & $<1.0$ \\
2 & $5.0 \times 10^{2}$ & $<1.0$ & $<1.0$ & $<1.0$ \\
3 & $<1.0$ & $<1.0$ & $<1.0$ & $<1.0$ \\
4 & $<1.0$ & $1.3 \times 10^{3}$ & $<1.0$ & $<1.0$ \\
5 & $<1.0$ & $<1.0$ & $<1.0$ & $<1.0$ \\
6 & $1.4 \times 10^{3}$ & $<1.0$ & $2.0 \times 10^{2}$ & $<1.0$ \\
7 & $<1.0$ & $7.0 \times 10^{2}$ & $4.0 \times 10^{2}$ & $<1.0$ \\
8 & $2.0 \times 10^{2}$ & $1.0 \times 10^{2}$ & $<1.0$ & $<1.0$ \\
9 & $<1.0$ & $2.0 \times 10^{2}$ & $<1.0$ & $<1.0$ \\
10 & $5.2 \times 10^{3}$ & $1.1 \times 10^{3}$ & $<1.0$ & $1.0 \times 10^{2}$ \\
\hline
\end{tabular}

Morphological and biochemical tests

Analysis of the results obtained on the morphological test performed after Gram staining revealed presence of Gram-positive cocci that stained violet, and Gram-negative rods, which stained pink owing to their inability to retain crystal violet after exposure to the ethanol-acetone solution as a consequence of the high amount of lipids in their cell wall.

Gram-positive cocci grew on blood agar forming grape bunch- and chain-like patterns, which indicates the possible presence of Staphylococcus sp. and Enterococcus sp. The results obtained to evaluate environmental contamination by means of BHI agar revealed growth of diverse microorganisms, with presence of Gram-positive cocci and Gram-negative rods.

The biochemical tests indicated presence of microorganisms from various genera not only on the plates used for environment evaluation, but also on the plates used for the evaluation of efficacy of $2 \%$ chlorhexidine on antisepsis of the hands. The biochemical tests performed included catalase, TSI (Triple Sugar Iron), urease, motility, citrate, lysine decarboxylase, and lactose.

The catalase test, which is specific for Gram-positive cocci, allowed discrimination between the Staphylococcus and Streptococcus genera. The TSI (Triple Sugar Iron) test was carried out to detect the possible presence of Gram-negative cocci through a $\mathrm{pH}$ change that takes place when fermentation occurs, and that causes a color change from red to yellow (Figure
1B). The other biochemical tests were performed to identify other bacteria that were not identified by means of the TSI test. These tests comprised: the urease test, which detects enterobacteria such as those belonging to the genus Proteus (Figure 1C); the motility test, which identifies whether the bacterium is mobile or immobile and allows discrimination between Enterobacter and Klebsiella, for example; the citrate test, which identifies bacterial species that use citrate as the exclusive source of carbon and results in a change in the $\mathrm{pH}$ of the medium (Figure 1D); the lysine decarboxylase test, which determines the ability to decarboxylate lysine through the action of the enzyme lysine decarboxylase; and the lactose test, which identifies microorganisms positive (pink colonies) or negative (transparent colonies) for lactose (Figure 1E). All these tests have been described by Quinn et al. [7].

According to Koneman et al. [8], these results confirm the presence of the genera Pseudomonas sp., Escherichia sp., Enterobacter sp., Klebsiella sp., Proteus sp., and Shigella sp. (Tables $3 \& 4$ ).

\section{Antimicrobial susceptibility test}

The evaluation of bacterial resistance to the antibiotics most commonly used in veterinary medicine, by means of an antimicrobial susceptibility test, found that the bacteria exhibited high levels of resistance to chloramphenicol, metronidazole, cephalexin, ampicillin, clindamycin, enrofloxacin, ceftiofur, and tetracycline (Tables 5 and 6) [Figures $1 \mathrm{~F} \& 1 \mathrm{G}$ ]. 


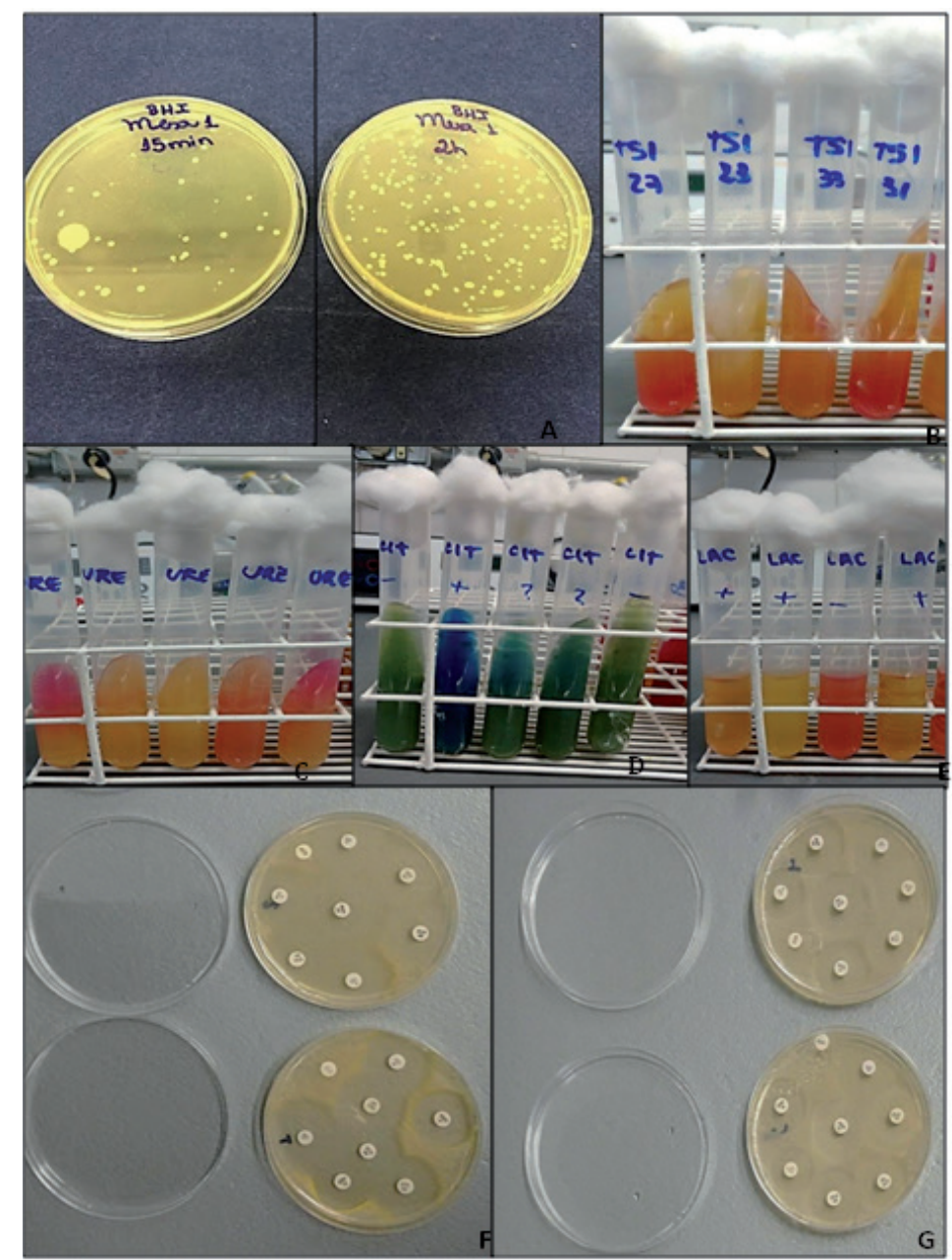

Figure 1. A- Petri dishes with BHI agar on countertops for $15 \mathrm{~min}$ and $2 \mathrm{~h}$ of surgical procedure; B- TSI test to identify Gram-negative cocci; C- Positive urease test (Tubes 1, 4, \& 5); D- Negative citrate test (Tubes 1 and 5); E- Positive lactase test (Tubes 1, 2 \& 4); F \& G- Bacterial multidrug resistance to some of the antibiotics most commonly used in veterinary medicine.

\section{DISCUSSION}

Even though the surgical unit of the Veterinary Hospital "Governador Laudo Natel" of Faculdade de Ciências Agrárias e Veterinárias (FCAV) at UNESP at Jaboticabal is constantly sanitized, it is not free from microbial contamination, as presence of bacteria on inert surfaces and equipment is common [9]. Additionally, presence of microorganisms in dust, clothes, skin fragments, and aerosols released while breathing contaminate the air in the surgical environment, and this contamination is proportional to the number of people present, their movement, and number of times that the door is open [10].

There was no bacterial growth on MacConkey agar; this indicates that, at the first sample collection time point (M0), gram-negative microorganisms were probably absent, which suggests absence of fecal contamination $[11,12]$. Blood agar is a culture medium that provides optimal growth conditions to most pathogenic bacteria [7], which explains the higher microbial growth observed in this medium. Gram-negative bacteria are more resistant to antiseptics and disinfectants owing to the lipid bilayer of their external membrane, which limits entrance of many antibacterial agents [7].

Analyzing the Tables 5 and 6 , it is possible to observe high bacterial resistance to metronidazole, followed by ampicillin. Metronidazole has bactericidal activity against most of the anaerobic and facultative anaerobic bacteria $[13,14]$; therefore, it is not effective against aerobic bacteria. This explains the result obtained with metronidazole, since the bacteria found were aerobic. As for ampicillin, it is considered a broad spectrum antibiotic that acts against Gram-positive and Gram-negative cocci and several genera of Gram-negative bacilli [15], which indicates that the bacteria found can be resistant to this antibiotic. 
Table 3. Microorganisms found in the operating room during environmental evaluation and obtained through biochemical tests.

\begin{tabular}{|c|c|c|c|}
\hline \multicolumn{4}{|c|}{ Environment } \\
\hline Sample & Morphology & $\mathrm{TSI}^{1}$ & Catalase $^{2}$ \\
\hline 1 & Gram-negative rods & Shighella sp. & \\
\hline 2 & Gram-negative rods & E. coli & \\
\hline 3 & Gram-positive cocci & & Negative \\
\hline 4 & Gram-positive cocci & & Positive \\
\hline 5 & Gram-negative rods & Pseudomonas sp. & \\
\hline 6 & Gram-negative rods & Enterobacter sp. & \\
\hline 7 & Gram-negative rods & Pseudomonas sp. & \\
\hline 8 & Gram-positive cocci & & Positive \\
\hline 9 & Gram-negative rods & Pseudomonas sp. & \\
\hline 10 & Gram-negative rods & Klebsiella sp. & \\
\hline 11 & Gram-positive cocci & & Positive \\
\hline 12 & Gram-negative rods & Proteus sp. & \\
\hline 13 & Gram-negative rods & E. coli & \\
\hline 14 & Gram-negative rods & Pseudomonas sp. & \\
\hline 15 & Gram-negative rods & Pseudomonas sp. & \\
\hline 16 & Gram-positive cocci & & Positive \\
\hline 17 & Gram-positive cocci & & Positive \\
\hline 18 & Gram-positive cocci & & Positive \\
\hline 19 & Gram-negative rods & Pseudomonas sp. & \\
\hline 20 & Gram-negative rods & E. coli & \\
\hline 21 & Gram-negative rods & E. coli & \\
\hline 22 & Gram-positive cocci & & Positive \\
\hline 23 & Gram-positive cocci & & Positive \\
\hline 24 & Gram-positive cocci & & Positive \\
\hline 25 & Gram-positive cocci & & Positive \\
\hline 26 & Gram-positive cocci & & Positive \\
\hline
\end{tabular}

${ }^{1}$ TSI: Triple sugar iron, biochemical test performed only to detect Gram-negative bacteria; ${ }^{2}$ Catalase: Biochemical test performed only to differentiate Gram-positive bacteria.

Clindamycin, a lincosamide, also resulted in bacterial high resistance, which shows that this drug was not effective against the Gram-positive bacteria found in the samples studied, since it normally acts against Gram-positive bacteria in addition to anaerobic bacteria [16]. Chloramphenicol is a broad spectrum antibiotic and inhibits bacterial protein synthesis, acting as a bacteriostatic drug [16]. Among all antibiotics tested, chloramphenicol was the one that showed the lowest level of bacterial resistance from the bacteria found in this study. Enrofloxacin, a fluoroquinolone, is exclusively used in veterinary medicine and acts against Gram-positive and Gram-negative bacteria, as well as anaerobic microorganisms [17]. According to the results obtained, enrofloxacin yielded high bacterial resistance indicating that wide use of this drug due to its intrinsic efficacy and safety might have contributed to the appearance of resistance [18]. Gram-negative bacteria are considered susceptible to enrofloxacin; however, there are reports on the occurrence of resistance due to mutation and transfer of plasmids [19].

Both cephalexin and ceftiofur are cephalosporins. Cephalexin is a first-generation cephalosporin and acts against Gram-positive bacteria, while ceftiofur 
Table 4. Microorganisms found on hand before and after antisepsis using $2 \%$ chlorhexidine brush.

\begin{tabular}{cll}
\hline & Blood agar & \\
\hline Sample & Morphology & Catalase \\
\hline 1 & Cocci/G + & Positive \\
2 & Cocci/G + & Positive \\
3 & Cocci/G + & Negative \\
4 & Cocci $/ \mathrm{G}+$ & Negative \\
5 & Cocci/G + & Positive \\
6 & Cocci/G + & Positive \\
7 & Cocci/G + & Positive \\
8 & Cocci/G + & Positive \\
9 & Cocci/G + & Positive \\
10 & Cocci/G + & Positive \\
\hline
\end{tabular}

Table 5. Antimicrobial susceptibility profile to drugs isolated from hands of mock surgeons.

\begin{tabular}{ccccccccc}
\hline Sample & CLO & MTZ & CEP & AMP & CLI & ENO & CTF & TET \\
\hline 1 & - & $\mathrm{R}$ & - & $\mathrm{R}$ & - & - & - & - \\
2 & - & $\mathrm{R}$ & - & $\mathrm{R}$ & - & - & - & - \\
3 & - & $\mathrm{R}$ & - & $\mathrm{R}$ & $\mathrm{R}$ & - & - & - \\
4 & - & $\mathrm{R}$ & - & $\mathrm{R}$ & - & - & - & - \\
5 & - & $\mathrm{R}$ & - & $\mathrm{R}$ & - & $\mathrm{R}$ & - & - \\
6 & - & $\mathrm{R}$ & - & $\mathrm{R}$ & - & $\mathrm{R}$ & - & - \\
7 & - & $\mathrm{R}$ & - & - & - & - & - & - \\
8 & - & $\mathrm{R}$ & - & $\mathrm{R}$ & - & $\mathrm{R}$ & - & - \\
9 & $\mathrm{R}$ & $\mathrm{R}$ & $\mathrm{R}$ & $\mathrm{R}$ & - & $\mathrm{R}$ & $\mathrm{R}$ & $\mathrm{R}$ \\
10 & $\mathrm{R}$ & $\mathrm{R}$ & $\mathrm{R}$ & $\mathrm{R}$ & $\mathrm{R}$ & $\mathrm{R}$ & - & $\mathrm{R}$ \\
\hline
\end{tabular}

CLO: Chloramphenicol, MTZ: Metronidazole, CEP: Cephalexin, AMP: Ampicillin, CLI: Clindamycin, ENO: Enrofloxacin, CTF: Ceftiofur, and TET: Tetracycline; (-) Susceptible and (R) Resistant.

is third-generation, which acts better against Gram-negative bacteria and less against Gram-positive bacteria [20]. Results showed bacterial resistance to cephalexin, possibly indicating a lower efficacy in treatment against bacterial diseases, since a lot of the samples were Gram-positive. Bacterial resistance to ceftiofur was lower when compared to cephalexin; this can be related to the shorter time this drug has been in the market, since it is a more recent drug (third-generation). Tetracycline is a broad spectrum drug, which acts against Gram-positive and Gram-negative bacteria and other microorganisms, also used as an antiparasitic drug [21]. This might have contributed to selection of resistant bacteria, as shown in the results.
The development of bacterial resistance to antibiotics is caused by spontaneous mutation and gene recombination, which acts on natural selection via genetic variability [22], and causes the drug to act as a selection agent [23]. Another factor that contributes to the emergence of resistance is the indiscriminate use of antibiotics for the treatment of animals, which can contribute to bacterial resistance in both animals and humans [19,24].

Lack of laboratorial diagnosis worsens the situation, together with underdosing or suspension of treatment without observing the specified treatment time, which increases the development of bacterial resistance [22]. Intensive use of antibiotics in animal feed and agriculture also contributes to selection of resistant microorganisms [25]. 
Table 6. Antimicrobial susceptibility profile of bacteria isolated from the surgical environment.

\begin{tabular}{|c|c|c|c|c|c|c|c|c|}
\hline Sample & CLO & MTZ & CEP & AMP & CLI & ENO & CTF & TET \\
\hline 1 & - & $\mathrm{R}$ & - & - & - & - & - & - \\
\hline 2 & $\mathrm{R}$ & $\mathrm{R}$ & $\mathrm{R}$ & $\mathrm{R}$ & $\mathrm{R}$ & $\mathrm{R}$ & $\mathrm{R}$ & - \\
\hline 3 & - & $\mathrm{R}$ & - & $\mathrm{R}$ & $\mathrm{R}$ & - & - & - \\
\hline 4 & - & $\mathrm{R}$ & - & $\mathrm{R}$ & $\mathrm{R}$ & - & - & - \\
\hline 5 & - & $\mathrm{R}$ & $\mathrm{R}$ & $\mathrm{R}$ & $\mathrm{R}$ & - & $\mathrm{R}$ & - \\
\hline 6 & - & $\mathrm{R}$ & $\mathrm{R}$ & $\mathrm{R}$ & $\mathrm{R}$ & $\mathrm{R}$ & $\mathrm{R}$ & - \\
\hline 7 & - & $\mathrm{R}$ & $\mathrm{R}$ & $\mathrm{R}$ & $\mathrm{R}$ & $\mathrm{R}$ & $\mathrm{R}$ & $\mathrm{R}$ \\
\hline 8 & - & $\mathrm{R}$ & $\mathrm{R}$ & $\mathrm{R}$ & $\mathrm{R}$ & $\mathrm{R}$ & $\mathrm{R}$ & $\mathrm{R}$ \\
\hline 9 & - & $\mathrm{R}$ & $\mathrm{R}$ & $\mathrm{R}$ & $\mathrm{R}$ & $\mathrm{R}$ & $\mathrm{R}$ & - \\
\hline 10 & - & $\mathrm{R}$ & - & $\mathrm{R}$ & $\mathrm{R}$ & $\mathrm{R}$ & - & - \\
\hline 11 & - & $\mathrm{R}$ & - & $\mathrm{R}$ & $\mathrm{R}$ & $\mathrm{R}$ & - & - \\
\hline 12 & - & $\mathrm{R}$ & $\mathrm{R}$ & $\mathrm{R}$ & $\mathrm{R}$ & $\mathrm{R}$ & - & $\mathrm{R}$ \\
\hline 13 & $\mathrm{R}$ & $\mathrm{R}$ & $\mathrm{R}$ & $\mathrm{R}$ & $\mathrm{R}$ & $\mathrm{R}$ & $\mathrm{R}$ & $\mathrm{R}$ \\
\hline 14 & - & $\mathrm{R}$ & - & $\mathrm{R}$ & $\mathrm{R}$ & $\mathrm{R}$ & - & $\mathrm{R}$ \\
\hline 15 & - & $\mathrm{R}$ & - & $\mathrm{R}$ & $\mathrm{R}$ & $\mathrm{R}$ & - & $\mathrm{R}$ \\
\hline 16 & - & $\mathrm{R}$ & - & $\mathrm{R}$ & $\mathrm{R}$ & - & - & $\mathrm{R}$ \\
\hline 17 & - & $\mathrm{R}$ & $\mathrm{R}$ & $\mathrm{R}$ & $\mathrm{R}$ & $\mathrm{R}$ & - & $\mathrm{R}$ \\
\hline 18 & - & $\mathrm{R}$ & - & $\mathrm{R}$ & $\mathrm{R}$ & $\mathrm{R}$ & - & - \\
\hline 19 & $\mathrm{R}$ & $\mathrm{R}$ & $\mathrm{R}$ & $\mathrm{R}$ & $\mathrm{R}$ & $\mathrm{R}$ & $\mathrm{R}$ & $\mathrm{R}$ \\
\hline 20 & - & $\mathrm{R}$ & $\mathrm{R}$ & - & - & $\mathrm{R}$ & $\mathrm{R}$ & - \\
\hline 21 & - & $\mathrm{R}$ & - & $\mathrm{R}$ & - & - & - & $\mathrm{R}$ \\
\hline 22 & - & $\mathrm{R}$ & - & - & - & $\mathrm{R}$ & - & - \\
\hline 23 & - & $\mathrm{R}$ & - & $\mathrm{R}$ & - & - & - & - \\
\hline 24 & $\mathrm{R}$ & $\mathrm{R}$ & - & - & $\mathrm{R}$ & - & - & - \\
\hline 25 & - & $\mathrm{R}$ & - & $\mathrm{R}$ & - & $\mathrm{R}$ & - & - \\
\hline 26 & $\mathrm{R}$ & $\mathrm{R}$ & - & $\mathrm{R}$ & $\mathrm{R}$ & $\mathrm{R}$ & - & - \\
\hline
\end{tabular}

CLO: Chloramphenicol, MTZ: Metronidazole, CEP: Cephalexin, AMP: Ampicillin, CLI: Clindamycin, ENO: Enrofloxacin, CTF: Ceftiofur, and TET: Tetracycline; (-) Susceptible and (R) Resistant.

\section{CONCLUSIONS}

The use of $2 \%$ chlorhexidine brush was effective for hand antisepsis for the period evaluated ( $2 \mathrm{~h}$ ). However, there should be an increase in hygiene measures and surgical environment cleaning. Antimicrobial drugs should be used more consciously to prevent the development of resistant bacteria and avoid future risks related to animal health as well as human health.

\section{MANUFACTURERS}

${ }^{1}$ Rioquímica. São José do Rio Preto, SP, Brazil.
${ }^{2}$ Plast Labor Microbiologia. Rio de Janeiro, RJ, Brazil.

${ }^{3}$ Kasvi - Produtos Laboratoriais. Curitiba, PR, Brazil.

${ }^{4}$ Oxoid Microbiology Products. Hampshire, UK.

${ }^{5}$ DME - Diagnósticos Microbiológicos Especializados. Araçatuba, SP, Brazil.

${ }^{6}$ Cefar Diagnóstica Ltda. - Vet. São Paulo, SP, Brazil.

${ }^{7}$ Laborclin Produtos Para Laboratórios Ltda. Pinhais, PR, Brazil.

Acknowledgements. Thanks to FCAV, to the Veterinary Hospital at FCAV, and to all people involved in this project.

Declaration of interest. The authors report no conflicts of interest. The authors alone are responsible for the content and writing of the paper. 
J.L. Gobbo, M.V. Cardozo, L.C.C. Lacerda, et al. 2017. Evaluation of Operating Room Environment Contamination and Efficacy of

\section{REFERENCES}

1 Werneck H.F., Lima K.C., Alviano C.S. \& Uzeda M. 1999. Ação Imediata de Diferentes Substâncias sobre a Microbiota das Mãos. Revista Brasileira de Medicina. 56(1/2): 42-50.

2 Wannmacher L. 2004. Uso indiscriminado de antibióticos e resistência microbiana: Uma guerra perdida. Uso racional de medicamentos: temas selecionados. 1(4): 1-6.

3 Santos L.R., Scalco-Neto J.F., Rizzo N.N., Bastiani P.V., Oliveira V.M., Boscardin G., Rodrigues L.B., Barcellos H.H.A. \& Brum M.V. 2007. A eficácia de desinfetantes e anti-sépticos empregados no Hospital Veterinário da UPF (HV-UPF) Brasil. Revista da FZAV. 14(2): 156-164.

4 Moriya T. \& Móderna J.L.P. 2008. Assepsia e antissepsia: técnicas de esterilização. Medicina Ribeirão Preto. 41(3): 265-273.

5 American Public Health Association. 1998. Standard methods for the examination of water and wastewater. 20th edn. New York: American Public Health Association, 848p.

6 CLSI - Clinical and Laboratory Standard Institute. 2009. Performance Standards for Antimicrobial Disk Susceptibility Tests, CLSI Document MO2-A10. Wayne: Clinical and Laboratory Standard Institute, 172p.

7 Quinn P.J., Markey B.K., Carter M.E., Donnelly W.J.C., Leonard F.C. \& Maguire D. 2005. Veterinary Microbiology and Microbial Disease. Ames: Iowa State University Press, 536p.

8 Koneman E.W., Allen S.D., Janda W.M., Schreckenberger P.C. \& Winn Jr. W.C. 2001. Diagnóstico Microbiológico. Texto e Atlas Colorido. 5.ed. Rio de Janeiro: MEDSI, pp.141-147.

9 Kayabas U., Bayraktar M., Otlu B., Ugras M., Ersoy Y., Bayindir Y. \& Durmaz R. 2008. An outbreak of Pseudomonas aeruginosa because of inadequate disinfection procedures in a urology unite: A pulsed-field gel electrophoresis - based epidemiologic study. American Journal of Infection Control. 36(1): 33-38.

10 Mangram A.J., Horan T.C., Pearson M.I., Silver L.C. \& Jaris W.R. 1999. Guideline for prevention of surgical site infection. American Journal of Infection Control. 27(2): 97-134.

11 Stephens J., Kinger R. \& Kettering J. 1994. In vitro comparison of the effectiveness of three surface disinfectants. Journal of the California Dental Association. 22(6): 40-42.

12 Jorge A.O.C. 1997. Microbiologia: atividades práticas. São Paulo: Livraria Editora Santos, 146 p.

13 Fenner W.R., Ettinger S.J. \& Feldman E.C. 2004. Doenças do cérebro. Tratado de Medicina Interna Veterinária: doenças do cão e do gato. 1: 586-638.

14 Patel K., Green-Hopkins I., Lu S. \& Tunkel A.R. 2008. Cerebellar ataxia following prolonged use of metronidazole: case report and literature review. International Journal of Infectious Diseases. 12(6): e111-e114.

15 Greenberger P.A. 1996. Drug allergies. In: Clinical immunology principles and practice. Saint Louis: Mosby, pp.988999.

16 Carvalho F.L.Q. \& Silva P. 2002. Farmacologia. In: Silva P. (Ed). Lincosamidas, Tetraciclinas e Cloranfenicol. 6.ed. Rio de Janeiro: Guanabara Koogan, pp.1049-1055.

17 da Silva J.M.B. \& Hollenbach C.B. 2010. Fluorquinolonas x Resistência Bacteriana na Medicina Veterinária, Arquivos do Instituto Biológico. 77(2): 363-369.

18 Cohn L.A., Gary A.T., Fales W.H. \& Madsen R.W. 2003. Trends in fluoroquinolone resistance of bacteria isolated from canine urinary tracts. Journal of Veterinary Diagnostic Investigation. 15(4): 338-343.

19 Pallo-Zimmerman, L.M., Byron, J.K. \& Graves, T.K. 2010. Fluoroquinolones: then and now. Compendium on Continuing Education for Veterinarians. 32: 1-9.

20 Climeni B.S.O., Dellalibera F.L., Monteiro M.V., Bazan, C.T. \& Pereira D.M. 2009. Cefalosporinas: sua origem, uso e função em animais de grande e pequeno porte. Revista Científica Eletrônica de Medicina Veterinária. 12: 1-8.

21 Granato P.C. 2011. Aspectos sobre a resistência bacteriana à tetraciclina (revisão de literatura), Universidade de Brasilia, Faculdade de Agronomia e Medicina Veterinária. Available at <http://bdm.unb.br/handle/10483/1860> [Accessed online in January 2017].

22 Mota R.A., Silva K.P.C., Freitas M.F.L., Porto W.J.N. \& Silva L.B.G. 2005. Utilização indiscriminada de antimicrobianos e sua contribuição à multirresitência bacteriana. Brazilian Journal of Veterinary Research and Animal Science. 42(6): 465-470. 
J.L. Gobbo, M.V. Cardozo, L.C.C. Lacerda, et al. 2017. Evaluation of Operating Room Environment Contamination and Efficacy of 2\% Chlorhexidine for Surgical Hand Scrubbing before and after Gowning and Gloving. Acta Scientiae Veterinariae. $45: 1484$.

23 Souza C.S. 1998. Uma guerra quase perdida. Revista Ciência Hoje. 23(138): 27-35.

24 Pedersen K., Jensen H., Finster K., Jensen V.F. \& Heuer O.E. 2007. Occurrence of antimicrobial resistance in bacteria from diagnostic sample from dogs. Journal of Antimicrobial Chemotherapy. 60(4): 775-781.

25 Manie T., Khan S., Brözel V.S., Veith W.J. \& Gouws P.A. 1998. Antimicrobial resistance of bacteria isolated from slaughtered and retail chickens in South Africa. Letters in Applied Microbiology. 26(4): 253-258. 